\title{
A Few Words About the Ice House of the Konsum Store in the Nineteenth-Century Priest's Mill Factory and Residential Complex in Łódź
}

People gathered, stored, and used real ice for purposes connected with business activity and food already in the antiquity and, according to Adrian Wessel Reinink (1995: 80n), 'the line of development' of such activity

...bei China begänne (für das es die ältesten Daten gibt) und dann über den Iran, die anderen Ländern des Islam, Spanien, Sizilien, dem übrigen Italien, Frankreich, England und den anderen Ländern Europas führte...,

where it was still conducted before the end of the sixteenth century. The 'other countries' include Poland, where the term 'lodownia' ('ice pit' or 'ice house'1) was first used in Polish sources during that period ${ }^{2}$. Admittedly, Bartłomiej of Bydgoszcz did not know it yet, or at least did not include it in his 1532 and 1544 dictionaries (Stownik Barttomieja... 1999-201933), but at the same time, in 1543, it appeared in crown land books, in a statement of expenditures on the Wawel

I In Polish, the term 'lodownia' is used to describe the objects discussed in this article, regardless of their construction or materials used. I will use the latter of the two English terms consistently.

2 On the other hand, as Andrzej Kola wrote (1989: 103) a simple... way to use ice was most probably known to peoples living in our land in the prehistory and the Middle Ages...

3 He does know, however, as does Jan Mączyński in 1564, the relevant Latin term - 'frigidarium', translated by them as 'chłodnica' (Mączyński 1564: 137; Stownik Barttomieja... 1999: IOI). 
Royal Castle (Wawel... 1913: 3II $)^{4}$. It seems that it soon grew in popularity, and so 'lodownia pewna' ('a certain ice house') is to Jakub Ponętowski (1937: I42), who died in 1586 , an indispensable element of a perfect manor. On the other hand his contemporary Anzelm Gostomski believed it was important

lodownie w dworzech, gdzie Pan bywa mają być opatrywane, aby lód nie ginął, a na czas zime był chowan

to keep ice houses in manors, where the Lord stays, supplied so that ice is not wasted and it is stored cold (Gostomski I588: 70),

while Duke Krzysztof Radziwiłt, in an instruction manual from 1621, ordered the administrator of his Vilnius palace

do lodowniej czasu swego lodu dostatek nagotować, kądz w nię włożyć tak, jakom ukazał, ażeby była zawsze zamczysta lodownia, naprawić

to prepare enough ice for the ice house in time and to put a vat in it like I have shown; and to repair the ice house so that it is always properly locked (Instrukcijos... 1985: I).

However, it should be emphasised that all men mentioned above were representatives of the Polish gentry, so they most probably expressed the views of this class. It is difficult to say something about the presence of ice houses in the manors of middle and petty nobles. Perhaps their interest in ice houses was smaller as they are only occasionally mentioned in the seventeenth- and eighteenth-century inventories of smaller estates. If so, this might by why 'ice houses' cannot be found in popular works by Jan Krzysztof Haur (1675; 1679; 1693) addressed to a wider audience. However, he was familiar with such structures as he mentioned cooling drinks with ice in the summer, at the same time expressing an opinion that drinking them was not healthy (Haur 1679: 109).

There are few mentions of ice houses in royal estates used by the gentry. They are more frequently referred to in the case of church estates, mostly in towns belonging to bishops, and particularly in those with bishop's courts.

Moreover, the form of inventories, and especially their succinctness with regard to elements of property that were of lower economic significance, makes it no easier to get to know the objects described better. Typically, they only provide the location of the ice house within the manor or the farm, rarely also the village. We are sometimes informed about the state of the object (particularly when it is poor), and only sporadically about some details of its structure. However, even then we

4 There are numerous references to Wawel ice houses in this collection of sources (Wawel... 1913: 31I, 365, 4IO, 4I7, 4I8, 4I9, 43I, 438, 440, 450, 454, 459, 474, 509, 517, 557, 74I). 
learn little, just like in the case of the ice house in Gródek on the Bug in Podlasie, where in 1604 it was noted that lodownia przy tej piwnicy z kamienia murowana, w której lodów dobrze bywa. To budowanie stoma poszyte (there is masonry ice house at the cellar, in which lots of ice is stored. It is thatched), or in Kompina in Mazovia, where in 1685 there was lodownia w ziemi kopana, dylami obtożona z wierzchu snopkami poszyta (an ice house dug out in the ground, covered with wooden beams and sheaves). Manor accounts provide even more succinct information, which usually concerns payment for the construction or demolition of the structure, repairs, worn or missing elements (e.g. Wawel... 1913: 365, 410, 417, 418, 438, 450, $454,459,474$ ), and people chopping ice for the ice house (e.g. ADPt, B-4: 8IV; B-34I: I30; B-344: I02; AGAD, APP, 8I: 43; Wawel... I913: 311, 4IO, 417, 438, 479, 509).

Such accounts do not leave readers much room for interpretation. Particularly, readers cannot say much about the reason behind the construction of each of these ice houses. They could be used for storing food cooled with the ice, at the same time ensuring that the food was easily available whenever necessary. However, they could only be places where ice was stored, protected against the weather ${ }^{5}$. In fact, we are clearly informed about their use in Poland at the time for the first of the purposes listed by guide-like descriptions of such structures, which seem to have first appeared in Poland at the end of the first half of the eighteenth century. One of the oldest can be found in Informacja matematyczna... (Bystrzonowski 1743), which is a compilation of earlier texts, mostly from the Historical and Political Calendar published by the Jesuits from Lublin. We can learn from it that

lodownią łatwo bez wielkiego kosztu sporządzisz w ten sposób. Na suchym miejscu wybierz loch głęboki, szyję mu dawszy na północ bez żadnego oddechu. Ku końcu zimy gdy lody pierwsze schodzić mają; zbierz w tafle porąbany. Słomą prostą wysławszy loch, lód w nim złóż i szyję chrustem ziemią załóż aby wiatr nie dochodził. Będziesz miał w najgorętsze lato dla wygody lód i lodownią, w której mięsiwo, zwierzyny, jak w pół zimy konserwować możesz

you can easily, without high cost, make an ice house as follows. Choose a deep dungeon in a dry spot, with a northern part without any draught. When the first ice is to break at the end of winter, collect it cut into sheets. Having covered the dungeon with simple straw, place ice there, and cover the opening with earth and brush so that no wind gets inside. In the hottest summer you will have ice and an ice house, in which meat and game you can preserve as in the middle of winter.

Though brief, the description lists all basic conditions that had to be met to ensure proper functioning of the building. Later descriptions of ice houses, meant for

5 Using ice houses for storing ice to be used in other, nearby places, or even building ice mounds instead was still recommended in the second half of the twentieth century by Wiktor Kurpisz (I952: III-I2O; 1956: 212-233). 
Polish readers and found in the works of Piotr Świtkowski (1782) and Franz Rausch (1788), are much longer and more exhaustive. However, more studies concerning the issue - even if some are very short - only appear in the nineteenth and twentieth centuries, mostly in magazines published at the time (e.g. O lodach... I822: 24I-243; Kostrzecki 1840: 264-265; Lodownia wiejska... 1865: 100), less frequently in encyclopaedic entries (e.g. Encyklopedja rolnicza... I889: 380-38I), and naturally in the form of passages in how-to books (e.g. Harres I883: 187-192; Iwanicki 1917: 247-251; Holewiński 1919: 13I-133). However, they are no match to similar, particularly German, studies (a list of such works see: Heintze 20I4), which they were usually based on both in terms of text and illustrations ${ }^{6}$. As a whole, Polish works are unique on account of one aspect: the remarks they contain typically refer to home and farm ice houses, with very few discussions of industrial and service ice houses (e.g. Ostrzeniewski 1902; 1906), and a few more brief mentions of existing or newly-built structures (e.g. Kamler 1910). It is a bit surprising as this happened even despite the fact that starting at least in the 1870 s, ice, also in Poland, was used on a large scale in breweries, municipal and private cold stores, slaughterhouses, markets, poorhouses, and hospitals, which were all institutions that needed a lot of ice throughout the year. For the same reason, demand for it appeared in eating establishments and some shops. The building discussed in this work belongs to the last category.

II

Researchers got interested in it in the autumn of 2014, when the Eódź press published reports of an accidental discovery of two 'mysterious' brick structures in the grounds of a workers' housing estate Priest's Mill (that also had had a German name Pfaffendorf), which used to belong to Karol Scheibler's cotton plant (cf. Pierzchała 20I4: 6; 20I4a: 5). Both were found directly at a building that had been erected as a store, mostly for the plant workers, and originally called Konsum, and later Konsumy. One of them - adjacent to the foundation of the southern wall of the building - was soon identified as a settling tank for waste from the store (Piechrzata 2014a: 5). The function of the other one, adjacent to the northern wall of the building and described either as hidden right under the turf rings of red brick, one [...] within the other, the distance between which is usually only $8 \mathrm{~cm}$ (Pierzchała 2014: 6) or as a double brick ring being a foundation of a mysterious building in the shape of a rotunda (Pierzchała 2014a: 5), remained unknown at the time. The daily press typically came up with more or less fantastical ideas suggesting that this could have been a gazebo, a food facility, or a storage room connected with the factory delicatessen

6 There are also some translations of foreign works (cf. Rausch 1779; Harres I882). 
(Pierzchała 20I4: 6). It seems, however, that this did not arouse great interest among readers, which is why the issue only returned to the press after nearly a year, when, on the initiative of the municipality and conservation services, the feature was investigated by employees of the ARCOS company, under the supervision of archaeologists Maciej Milczarek and Zbigniew Rybacki. The archaeologists, even though their work was limited to the exploration and documentation of the interior of the structure, soon identified it as a store ice house (Magnuszewska 20I5: 4; IZJ 2015a: I, 3; 2015b: 3; M. Kwiatkowski 2015: 4; Pietrzak et al. 2015).

The ice house - apart from analysis of the results of the archaeological research mentioned above (Pietrzak et al. 2015) - has not been described in the literature concerning the establishment and the functioning of the Priest's Mill estate (e.g. Popławska 1964: 298-306; 1972; 1992: 68-69, 94-99; Szyburska 1976; Turowski 1976; 1976a; Puś 1979; Pytlas 1979; 1998; Markiewicz-Kozańska 1982; 1984: 137-I4I; 1991; Kobojek 1998; Salm 1998; 200I; 2007; Stefański 200I: 97-IOI; 2003: 58-59; Walczak 2007; 2010: 103-105, 230; Tomczak 2012) or mostly unpublished conservator's studies (e.g. Szyburska 1972; Kajzer 1981; Pawłowski et al. 200I; Filipowicz 2012). Moreover, some of the above works fail to mention the store, while others only acknowledge its existence (Szyburska 1976: 106, 107, 112; Markiewicz-Kozańska 1984: 134, 136; Pytlas 1979: 72, 166; Salm 2001: 49; 2007: 75; Szymański 2006: 58; Tomczak 2012: I2; Walczak 2007: 63; 2010: 103, 104, 230), and only few devote more attention to it from different scientific perspectives

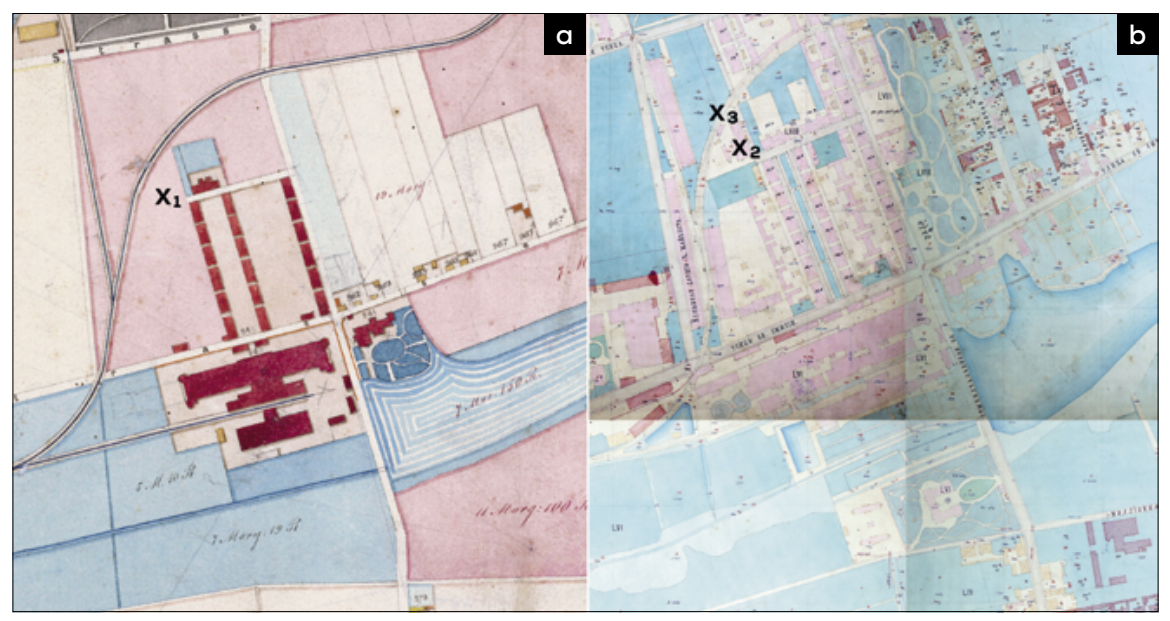

Fig. 1. The factory and residential complex Priest's Mill; a. - As of approx. I873; source: APE, Zb.kart. 527 (fragm.); b. - According to measurements from I894-I896 with later improvements from 1904-I906; source: APŁ, Zb.kart. I (fragm. sekc. XXXVIIII, XXXIX, XLV, XLVI). Legend: XI - location of the Konsum building; $\mathrm{x} 2$ - the Konsum building; $\mathrm{x}_{3}$ - the ice house. 


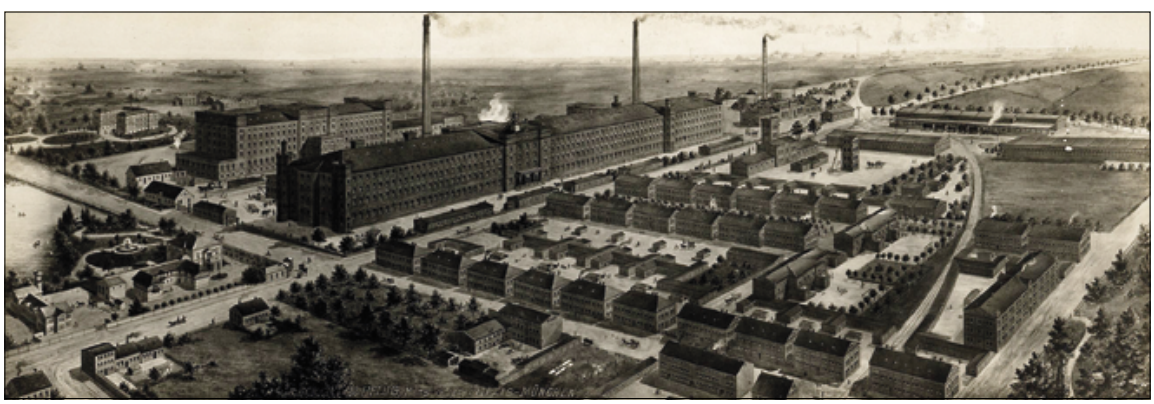

Fig. 2. The factory and residential complex Priest's Mill; a. - As of the period between I897 and I899; source: APŁ, Zb.alb.ikon., sygn. A-IO3, k. 2, photo I.

(Kajzer 1981; Kobojek 1998: 78-79; Pawłowski et al. 200I: II, I4, 5в, 6B; Salm 1998: 66-67; Filipowicz 2012), however, none is exhaustive7.

We know little particularly about the operation of the store, and our knowledge of the history of its construction is not full. However, in the case of the latter issue, field research and archival surveys conducted allow to formulate some hypotheses. First of all, it can be unequivocally stated that it was not built in the first years of the construction of Scheibler's factory estate, which started as early as in 1873 (Pawłowski et al. 2001: 5B; Pytlas 1979: 77) or only two years later (e.g. Popławska 1964: 301; 1973: 86; 1992: 96; Kobojek 1998: 78; Stefański 200I: 98; 2003: 59). What allows to conclude that the store was built a bit later is the fact that it was not included by Rudolf Miciński on the city map (or, in fact, a supplement to his older map) he drew in $\mathrm{I} 877$, which also, or even mostly (as it was created for Karol Scheibler), showed the development of all properties owned by Scheibler at the time (Fig. Ia) (APE, Zb.kart.: 527; cf. Kajzer 1981: 2). Moreover, it can be assumed that it was built even later than it is usually suggested in the literature, according to which it was erected around 1877 (Kajzer 1981: 2; Kobojek 1998: 78; Filipowicz 2012: 5), before 1878 (Walczak 2010: 104), or in 1879 (Pawłowski et al. 200I: 5B). Only Stefan Pytlas (1979: 166; cf. Tynecki 1988: 49; Kulesza 2013: 17) reported that the store for factory and office workers was established in 1882 . And this date is also given in a short description of the first years of the store's operation found in an account of the Industrial and Agricultural

7 The facility has been divided for some time now into two separate properties, with the following addresses: 14 Księży Młyn Street (plot no. 92/I, section W-25) and I6 Księży Młyn Street (plot no. 92/z, section w-25). In 20I2, Paweł Filipowicz conducted architectural research there (Filipowicz 20I2), and today both parts are subject to conservator's renovation of elevations and roofs conducted by the ATIK sp. z o.o. company based on a design created in the ARTA sp. z o.o. company by Danuta Włodarska and her colleagues (Włodarska et al. 2016; 2016a). 
Fair organised in Warsaw in 1885 . The account also makes the date more specific as its anonymous author writes that

The development of the store was so unexpectedly rapid that within only a few months the building erected for this purpose by the Association [Scheibler's Associations - J.P.] turned out to be too small and had to be extended in two ways... (Wystawa Przemystowo-Rolnicza... 1885: 113).

And as we know thanks to field research, such a considerable extension of the store building took place along with the implementation of the proposals outlined in the preserved plans of the facility extension dated April 28 (May IO), I883 (APE, RGP, WA I66I: 156; cf. Filipowicz 2012: 5), so it should probably be assumed that the original store was built (or at least opened) not later than in the middle of $\mathrm{I}^{8} 82^{8}$.

Moreover, considering the fact that a store - usually a grocery - was an integral element of many European factory and residential complexes supplementing their functional programme, particularly on estates located in the country or far from the city centre (Walczak 20I0: 230-23I), it is seems plausible that it was included in the original design of the Eódź complex. However, it is difficult to determine whether this was the case. There is no doubt that the original store in the Priest's Mill was relatively small, created mostly to provide for the basic needs of the residents. Such a purpose is confirmed by the already mentioned account of the fair, according to which the Association opened a grocery in order to [...] provide workers with healthy and cheap foodstuffs (Wystawa Przemystowo-Rolnicza... I885: I13).

Initially, it occupied a one-storey building without a basement, covered with a low gable roof. It was approx. $12.4 \times 25.8 \mathrm{~m}$, and its floor space was approx. $263 \mathrm{~m}^{2}$ (Fig. 3 - Stage I). It was built of mechanically made, well-fired solid clay bricks arranged in English cross bond (Dutch bond), joined with lime and sand mortar, and measuring $63-68 \times 128-138 \times 268-279 \mathrm{~mm}$, which was close not only to standard dimensions used in the Tsarist Russia (including Congress Poland) at the turn of the twentieth century, but also to the Polish Standard introduced in 1927 (cf. Ostap. 1911: 168; Domaniewski 1929; Bochenek 2003: 454)'.

8 The design was signed by the then city planner Hilary Majewski, which is why Grażynak Kobojek (1998: 78) concluded he was the author of the whole facility. However, research conducted by Krzysztof Stefański (1994; 1997; 2015: 59) and Jacek Strzałkowski (1997: 8-9, 90-97) indicates that while in office, H. Majewski frequently attributed works of other architects to himself, so it is impossible to take a definite stand on the issue.

9 A similar material and a similar technique were used to build walls during all stages of the extension described below. Later, mechanically made clay bricks were still used but with different dimensions, including solid bricks, cellular bricks, and chequers. The situation is similar in most buildings in the residential part of the Priest's Mill. 


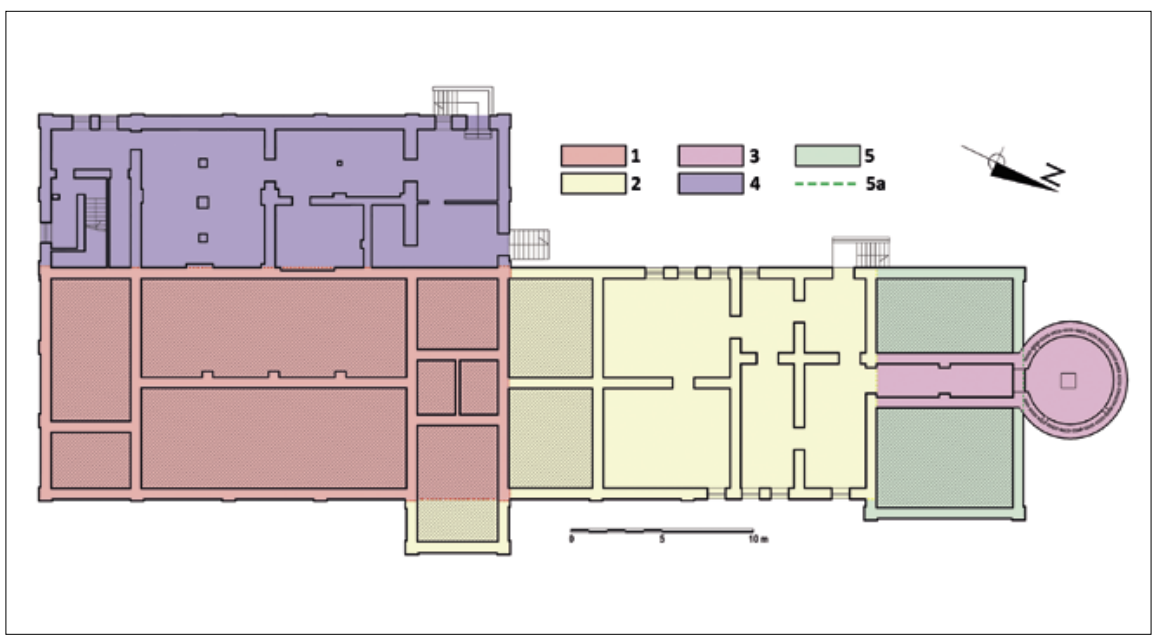

Fig. 3. The Konsum building. The basement plan, construction and extension stages. Legend: 1 - Stage I (I882); 2 - Stage II (I883/I884); 3 - Stage III (between I883/1884 and I889); 4 - Stage IV (I890/I89I); 5 - Stage V (after I897-I899); 5a - The extent of the northern wall of Stage v on the ground floor level; Author's own work based on the results of research carried out by P. Filipowicz (2OI2).

The building did not survive long in its original form because, as it was already mentioned, its extension was planned very soon, i.e. in the spring of 1883 (APE, RGP, WA I66I: 156; cf. Kajzer 1981; Filipowicz 20I2), and the already cited press article allows to assume that the work was carried in the same year (Wystawa Przemystowo-Rolnicza... 1885: I13). In consequence, the original building was extended towards the north with a one-storey section with a partial basement ${ }^{10}$, so that it became approx. $46.40 \mathrm{~m}$ long, with the width unchanged. A porch with a gable roof was also added (with a projection approx. $2.80 \times 5.70 \mathrm{~m}$ ) along the axis of the new, elongated eastern elevation, as a result of which the floor space increased to approx. $474 \mathrm{~m}^{2}$, while the basements in the annexe extended it further by approx. $143 \mathrm{~m}^{2}$ (Fig. 3 - Stage II; Fig. 4a).

Another extension of Konsum (Fig. 3 - Stage III) involved the construction of the ice house we are interested in (Pietrzak et al. 2015). It will be discussed further in this paper but two remarks have to be made now.

Firstly, we do not know when exactly it was built, and considering the present state of preservation - and partially also identification - of Scheibler's archives, we can only say that it was completed before July 29/August IO, 1890, when the existence of

IO Nearly all basements created at different stages of the extension had arched brick floors on steel beams, and the above-ground rooms - wooden-beam floors. 
this structure was marked in a layout drawing attached to the design concerning the area near the storehouse (APE, RGP, WB I569). Moreover, the fact that the ice house is not marked in a similar drawing to a design of an adjacent storehouse drawn up on July I5/27, I889 (APE, RGP, WB I569) seems to indicate that it was constructed between these dates. Unfortunately, it is excluded by the fact that no significance was attached to updating the layout drawing when creating plans for Scheibler's plants and submitting them to authorities for approval. For example, the ice house in question was marked on a plan dated February 22/March 6, 1891, but it is missing from the plans from August 25/September 6, I891 and from July 19/31, I893 (APE, RGP, WB I867; 2248; 3358).

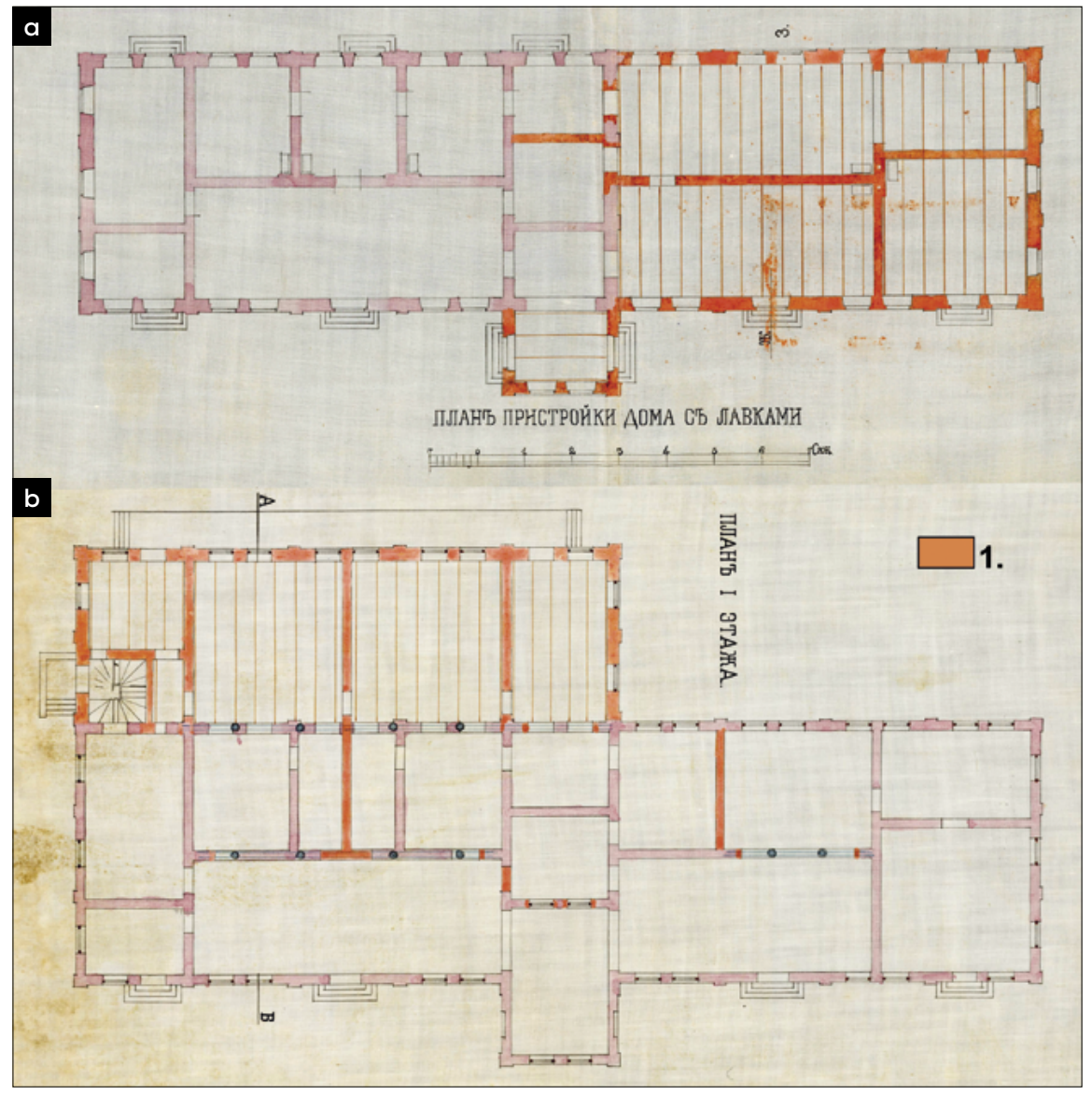

Fig. 4. The Konsum building; a. - A ground floor plan on the design of the first extension (Stage II), I883, source: APE, RGP, WA I66I: I56; b. - A ground floor plan on the design of the third extension (Stage IV), I890, source: APŁ, RGP, WB 1586. Legend: 1. Newly planned elements of the building. 


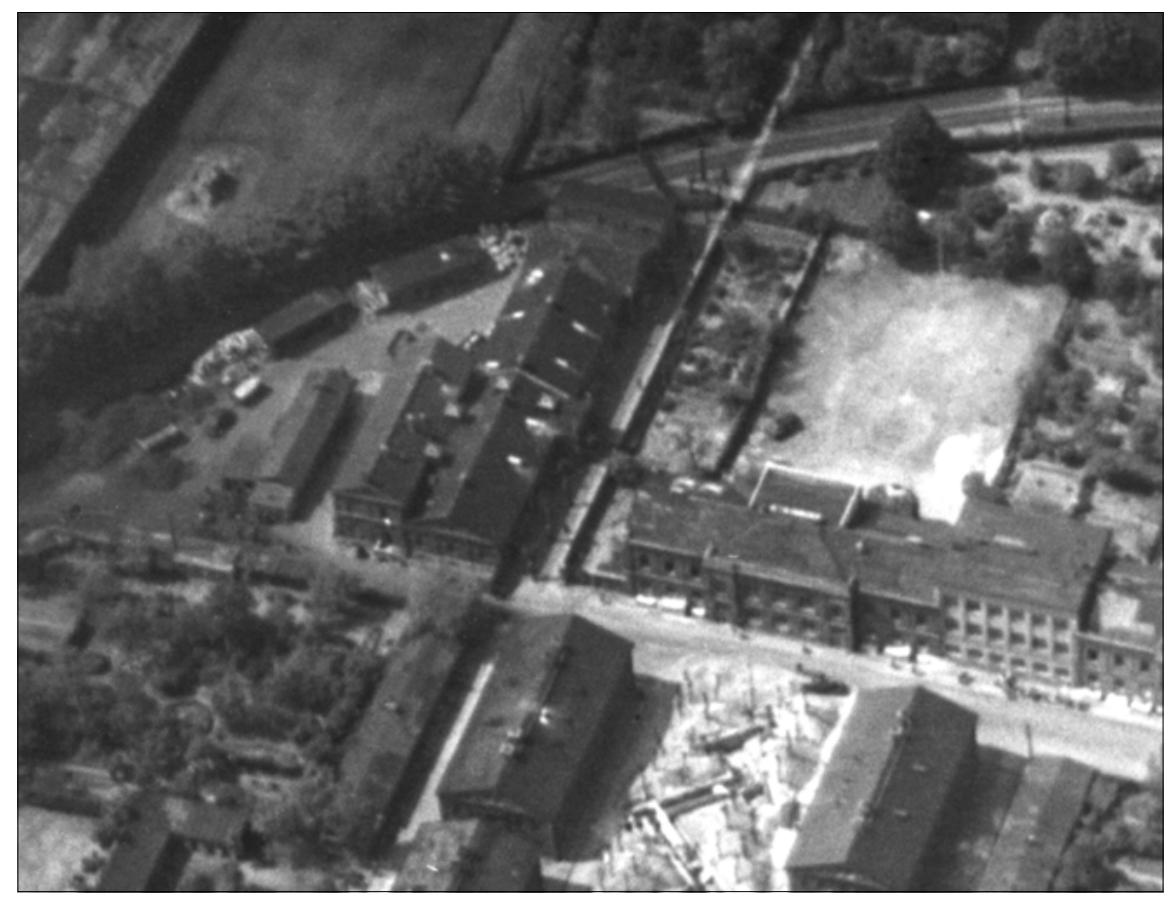

Fig. 5. The Konsum building on an aerial photograph from the Second World War, source: BFM, fm931927 (fragm.).

Secondly, there is no data that would allow us to determine the date of demolishing the structure. The archival survey did not provide any relevant information about it. The fact that the ice house is marked on the map of Łódź published by Kazimierz Jasiński in 1917 (APE, AME, WT 2II42) seems to suggest that it still operated at the time, however, this map is only a re-edition of an older map of Władysław Starzyński (Fig. Ib), which reflected the situation from the beginning of the last decade of the nineteenth century (APE, Zb.kart. I), i.e. soon after the ice house had been built. Community interviews did not provide any useful information either as despite some opinions that the structure was liquidated when electric store freezers became popular in the $1960 \mathrm{~s}^{11}$, people who had lived in the Priest's Mill for a few decades much more frequently said that they did not recall any such feature in this part of the estate. The last information seems to be confirmed by analysis of barely legible German aerial photographs taken during the Second World War, which suggests that the ice house might have been

II The opinions were voiced already after the press had published information about the purpose of the structure. 


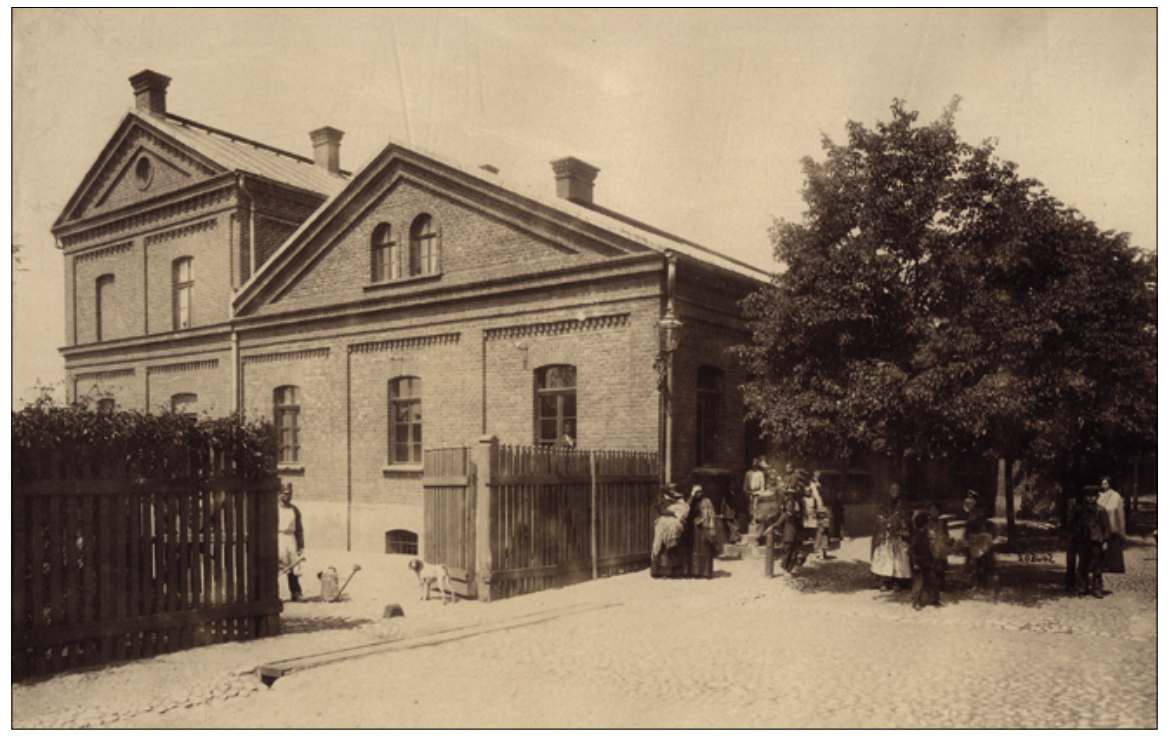

Fig. 6. The Konsum building. A view from the south-east as of the end of the nineteenth century (c I885?), source: APŁ, Zb.ikon. SiG: 239.

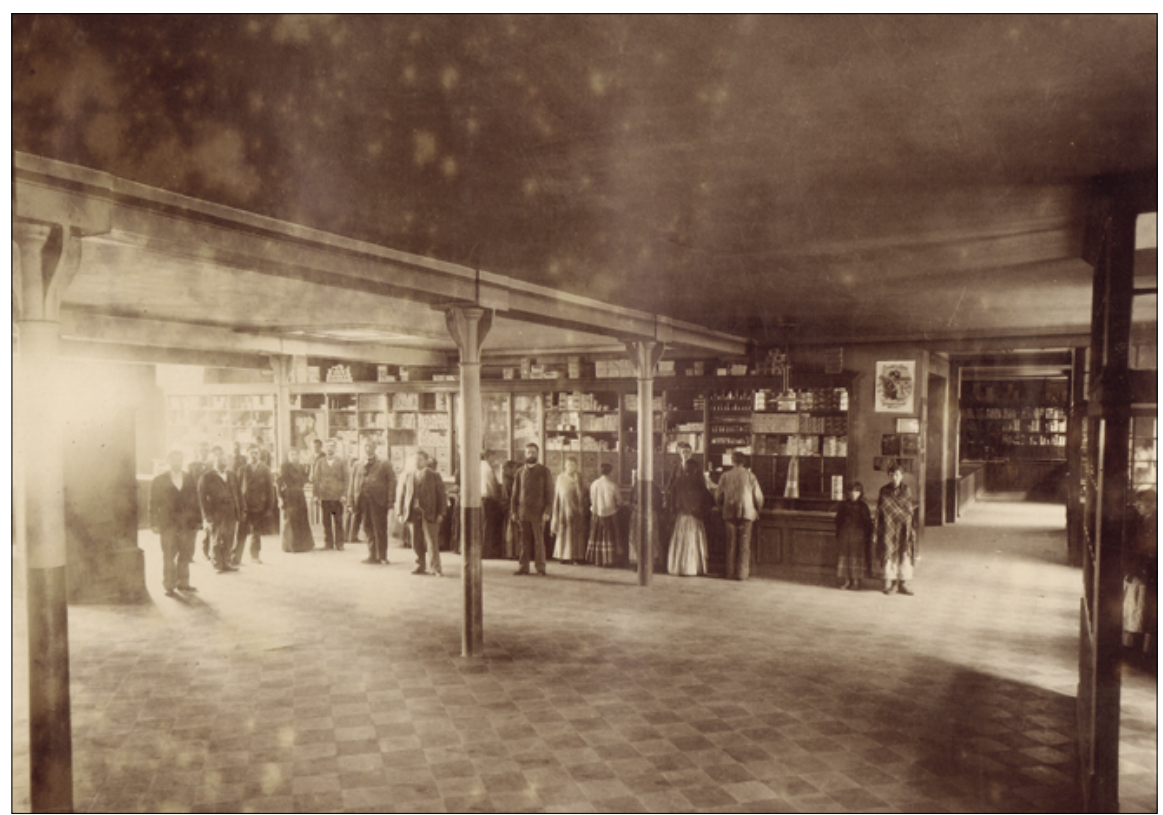

Fig. 7. The Konsum building. Interior of the shop floor as of the end of the nineteenth century (c I885?), source: APE, Zb.ikon. SiG: 240. 
gone at the time, and there was another, unknown to us, structure in its place (particularly: BFM fm931972) (Fig. 5) ${ }^{12}$.

Before the ice house was demolished, however, the store had been extended twice. The first extension (Fig. 4 - Stage IV; Fig. 4b, 6) was based - with a few modifications - on the preserved design created in August I890 (APE, RGP, WA I586) and it most probably took place before the end of August of the following year, when the new element was marked in a layout drawing created along with a construction plan of, among others, one-storey sheds with laundry rooms and toilets (APE, RGP, W B 2248). It was added from the west to the Konsum section erected during Stage I. It was built of brick, on a rectangular plan, measuring $8.55 \times 26.30 \mathrm{~m}$, with floor space of approx. $551 \mathrm{~m}^{2}$, including approx. $175 \mathrm{~m}^{2}$ on each of the two above-ground storeys and approx. $165 \mathrm{~m}^{2}$ in the basement.

Both sections of the newly created building were merged in spatial and functional terms on the ground floor, thus forming a large sales floor (Fig. 7), and the first floor of the added part was used for residential purposes.

During the last of the clearly Scheibler's extensions - conducted after I897-I899 (see Fig. 2-3, Io and below) - the ground floor of the store was extended towards the north, where a new one-storey brick section was added between the building wall and the ice house, virtually without a basement, measuring approx. 8.20 x $12.70 \mathrm{~m}$, with floor space on the ground floor of approx. $94 \mathrm{~m}^{2}$ (Fig. 3 - Stage v). It was built so that it formed a shallow wall projection in the north-eastern part of the eastern elevation, and its northern wall included a fragment of the ice house wall. It was also placed above the corridor linking the ice house with some of the store basements. Moreover, the ridge line of its gable roof was at right angles to the ridge lines of the roofs of the main building parts.

Thus, the Konsum building received the form we can basically see today, except for the demolished ice house. This does not mean, however, that it was not altered later as today, on the northern elevation of the one-storey part of the building, one can still see traces of two smaller annexes built after the ice house had been liquidated. The existence of the older one is proved by a regular, quadrangular patch of traditional stucco and a passage bricked up with cellular bricks joining its interior to a room in the store building. What remained of the other, younger and smaller annexe, is the mark of a gable roof 'painted' on plaster with roof cement. Other secondary elements, at least in the latest form, are (or, today, partly 'were') concrete ramps located along the western elevation. And finally, both interiors and elevations show traces of numerous small cuts-off and masonry rebuildings as well as larger alterations ${ }^{13}$.

I2 The ice house could have been enclosed by a new structure.

I3 This activities will be discussed in a paper prepared by Paweł Filipowicz and the Author. 
III

The main part of the ice house was built approx. $7.75 \mathrm{~m}$ to the north away from the store building extended during Stage II, and it was linked with its basements with an underground corridor mentioned above. It was built on a circular plan, with diameter of approx. 6.3 $\mathrm{m}$, with a foundation depth of 207.39-207.4I m above sea level, i.e. approx. I. $8 \mathrm{~m}$ below ground as of 2015 , when the excavation works started. This ground level (i.e. approx. $209.20 \mathrm{~m}$ above sea level) was most probably similar to the one from the time of the construction.

Virtually the only part of this structure that has survived until today is the underground section (Fig. 8). Paradoxically, this allowed to determine the method of building the perimeter wall of the main part. It consists of two concentric brick rings with outside diameter of up to $6.34 \mathrm{~m}$. The external one is $0.40 \mathrm{~m}$ thick (which corresponds to 1.5 brick lengths), while the internal one is $0.27 \mathrm{~m}$ thick (which is the length of one brick). The first of these two rings seems to have English bond brickwork, while the other - header bond. Both are separated with a space of approx. $0.10 \mathrm{~m}$ and they are joined with regularly spaced, one-brick tie-beams staggered every two layers. Both external and internal wall faces originally had no

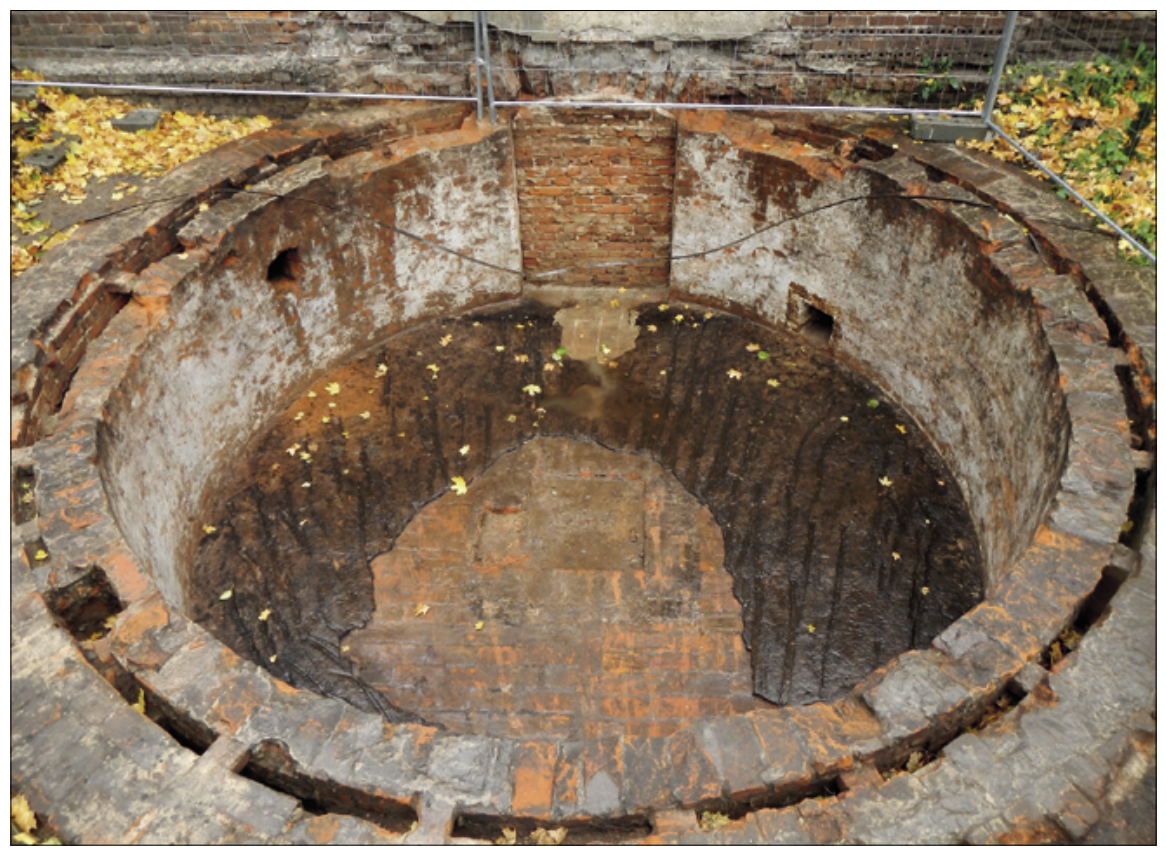

Fig. 8. The remains of the ice house at the Konsum building. A view from the north as of 20I5, photograph by Z. Rybacki and M. Milczarek. 
coating. Over time, however, the latter was sponge-painted with a thin layer of lime with traces of cement. Three openings were found in it. One is located I $m$ above the floor, measures approx. $0.28 \times 0.28 \mathrm{~m}$, reaches the expansion joint, and could have been made when the structure was built. The remaining two openings ${ }^{14}$ have similar dimensions but are located directly above the floor and they are definitely effects of later works. They are connected with air ducts (?) created by cutting the internal ring of the wall and lining thus created cavities.

The double wall surrounds cylindrical space with a diameter of $4.80 \mathrm{~m}$ (and floor surface of approx. $18 \mathrm{~m}^{2}$ ), with the bottom lined with clay bricks later (?) covered with a layer of bitumen adhesive mixed with coarse gravel. The flooring lies on a bedding with thickness of approx. $0.30 \mathrm{~m}$, mixed with crushed brick sand, which, in turn, lies on fine natural sand. It is nearly horizontal, and it only slightly (by about I\%) inclines towards the centre of the structure. In this place, one can see a shallow - approx. $0.03 \mathrm{~m}$ deep (207.36 m above sea level) - square hollow, measuring $0.80 \times 0.80 \mathrm{~m}$, the bottom of which is the crest of a spot footing made of bricks located at least $0.60 \mathrm{~m}$ below the floor level. On the crest, one can see traces of a mounting of a cast-iron or steel column.

In the southern part of the double ring, there is a bricked-up ${ }^{15}$, segmentally-arched passage that used to be linked to the already mentioned corridor under the central part of the one-storey part of the store building erected during the last extension stage (Fig. 4 - Stage III). The corridor, which today is rather useless space closed on one end, used to serve as an airlock, with double doors on both ends. It consisted of two chambers of the same length, separated with doors. Today, the corridor is covered with reinforced formwork cast slabs sitting on steel beams. However, it seems plausible that this structure was only created during Stage V of the extension as before that the roof-according to some nineteenth-century site plans of the estate (APE, RGP, W B I569; 1867) - was most probably located above the ground.

Over the bricked-in opening, there is a relatively small fragment of the aboveground section of the ice house wall, specifically its outer ring (Fig. 9), being a part of today's northern wall of the one-storey section of the building, approx. $3.30 \mathrm{~m}$ long and $4.40 \mathrm{~m}$ high $(213.60 \mathrm{~m} \text { above sea level })^{16}$. It does not, however, offer us much information as we can only conclude that up to approx. $211.80 \mathrm{~m}$ above sea level the wall consisted of two rings separated with a wide, thermal

I4 They were covered with a fine steel mesh.

I5 The bricks used were similar in size to the ones used to build the ice house and the store walls but they were fired far less thoroughly.

I6 It was only excavated in 2020 during conservator's renovation of the elevation conducted by ATIK sp. z o.o. 


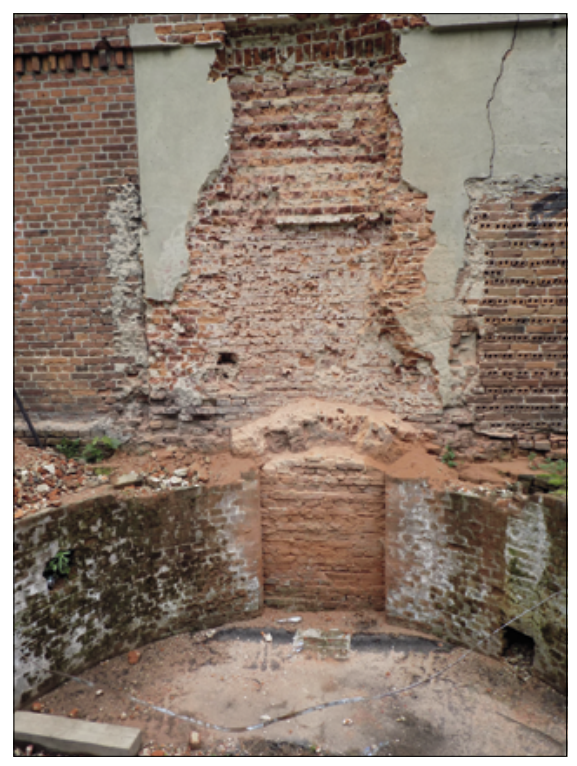

Fig. 9. The Konsum building. The northern elevation of the one-storey part with the remains of the ice house wall. A view from the north as of the summer of 2020 , photograph by J. Pietrzak

insulation space ${ }^{17}$, and above them the ice house wall was a solid brick wall.

The last solution most probably involved covering the building with a vault the form of which we are unable to determine today (e.g. Brückner, Spillner 1904: 254-255, Abb. 356-357). It is impossible to say how high it was, and so it is impossible to determine the volume of the ice house. It can only be supposed that it was more or less $100 \mathrm{~m}^{3}$. It can be said with reasonable certainty that the space was divided into two levels separated with a floor slab supported on the wall ring and additionally on a steel or cast-iron column. Moreover, there is no doubt that the upper chamber was used as an ice warehouse, while the lower was the store's cold storage, which is proved by the fact that in the latter there is no drainage for melting ice. Such a reversal of layout typical of an ice house was not unusual as it was also commonly used in the USA as well as in Europe, though mostly in industrial facilities, such as breweries. This solution ensured good air circulation ${ }^{18}$ as heavy cold air falling down to the floor of the warehouse displaced warmer air (Geul I884: 409; Plank 1954: 100, 134; Ellis, 1982: 19-20; Tangires 1991: 37, 42; Heintze 2008). This was extremely important not only because it ensured proper storage temperature but also because it allowed to maintain adequate humidity in the storage chamber; too high humidity would favour the development of microorganisms, while too low humidity would speed up the drying of the products stored and aromatic substance evaporation, which would lead to mass loss and, in consequence, financial losses (e.g. Brożkiewicz 1946: 16-17). On the other hand, this required a complete change in the management of melting ice, and this aroused some doubts about drainage effectiveness (Ulepszenia... 1867: 39).

I7 Numerous cases of such solutions adopted in the United Kingdom are presented by Sylvia P. Beamon and Susan Roaf (1990).

I8 In this case it was most probably insufficient as to improve it the internal wall ring was cut and the already mentioned air ducts were created. 


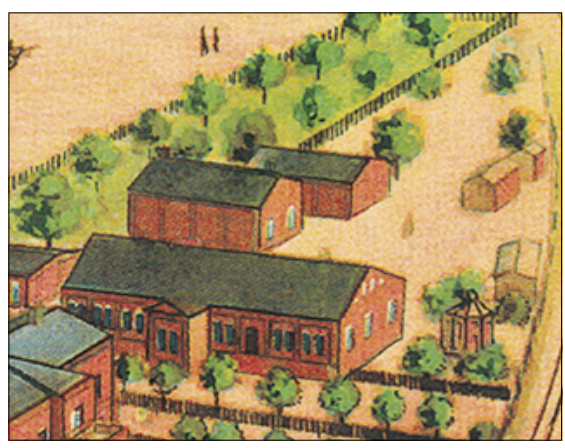

Fig. 10. The ice house at the Konsum building. A view from the north-east as of the period between 1897 and I899, source: Zjednoczone zaktady... (fragm.).

The general appearance and operation of the ice house described here can be to a certain extent supplemented with observations made based on its representation in a perspective veduta of the Priest's Mill estate showing its state between 1897 and 1899 (Fig. 2). Unfortunately, we only know this image from photographs of the original with signatures of ECKERT \& PFLUG, Kunstverlag LEIPZIG - MÜNCHEN (e.g. APE, Zb.alb.ikon. A-IO3, k.2, photo I) and its later adaptations (e.g. Zjednoczone Zaktady...). Moreover, even though it is seemingly quite detailed, it also contains some inaccuracies. Without listing these mostly minor mistakes, it should be noted that one of them concerned the form of Konsum, which had different elevations but was visualised as two separate one-storey buildings (Fig. 2; 10). The ice house in the veduta was depicted as a polygonal building with a pyramid-shaped, perhaps eight-plane, roof, which seems to be topped with a ventilation chimney. Possibly, there is an entrance to the ice house marked on the wall (Fig. Io).

However, nothing in the preserved remains of the ice house suggests that it used to be polygonal. Moreover, the already mentioned layout drawings and maps all depict it as a round structure. Its polygonal form may only be an illusion resulting from the fact that the author schematically marked panels on the wall of a round building, which were characteristic elements decorating brick elevations of the buildings in the Priest's Mill.

IV

Having discussed the issues indicated by the title of this paper, we can move on to conclusions. This time, however, they will not be limited to the object of the discussion. I am sure that Readers have noticed that the paper includes virtually no references to the state of research into ice houses in Poland. The is simply because this issue is almost absent from the scientific literature, which was already noted nearly twenty years ago by Andrzej Wilk (2000: 37-38) in a short article published in Spotkania z zabytkami within a series under a telling title To tez sq zabytki (These Are Also Monuments). Nothing has changed in this respect, which is surprising considering the fact that old manor and farm buildings included a considerable, though constantly falling, number of preserved, even if abandoned 
and demolished, ice houses. At the same time, they are elements of sites that are very popular research subjects among representatives of many fields. It is similar in the case of another considerable, though definitely smaller, group of ice houses, i.e. those connected with industrial facilities (mostly plants) and other institutions that in their production processes or activity first used real and then synthetic ice. However, the interest in whole complexes did not translate into a considerable increase in knowledge of their ice houses. It mostly resulted in many mentions of them in dozens or even hundreds of publications, but it is very difficult to find any in-depth study on the issue. Probably the only researcher that studied it closely was Renata Gubańska (2009: 50-53, 89), who devoted it some attention when investigating Lower Silesian manors and their buildings. Unfortunately, her findings only to a small extent went beyond nineteenth-century encyclopaedic studies. Others, like Małgorzata Rozbicka (1999: 76, 88, 90, 248, 252) and Bartłomiej Kwiatkowski (2012: 119-120, 155-156) discussed the issue only briefly or, like Jarosław Szewczyk (2019: 127, 162), focused on narrow, technical aspects. Of course, there are works providing some new observations and information about ice houses but they also repeat old common opinions (e.g. Kowecka 1991: 214; Sieradzka 2001: 53, 72, I44; Baraniewski 2004: 43-44; Zaprutko-Janicka 2017). On the other hand, in Western Europe and in the United States, ice houses have long constituted significant, stand-alone research issues. A number of monographs have been published (e.g. Reinink, Vermeulen 1981; Ellis 1982; Reinink 1995; Martin 1997; 2000; Lütgert 2000; Aterini 2007; Heintze 2014). They are of different quality but they well reflect the scale of the problem. At the same time, even though many of the theses advanced in these works seem to largely correspond with our realities considering the current state of knowledge of Polish ice houses, it is an a priori opinion that should be verified through extensive research. In order to conduct it, we need to know what we have. Thus, I will repeat the appeal of the already mentioned A. Wilk (2000: 38) to quickly start inventorying them [i.e. ice houses - J.P.] [...] but mostly to [...] popularise them, show their value, and prevent their decay. This appeal should or even must be supported with a remark that in order to effectively popularise something, it should be at least slightly known. 


\section{Bibliography}

\section{Archive resources}

\section{ADPł (Diocesan Archive in Płock)}

Ref. no. B-4: Inwentarz dóbr biskupstwa płockiego anni 1595 . Ze starego i na półzgniłego inwentarza przepisany in majori parte, reszta bowiem tego inwentarza w kapitularzu płockim pod ławą znalezionego rozpruszona, odarta i zgniła nie mogła być przeczytana. To zaś co tu się znajduje przepisane jest z rozkazu J[aśnie] W[ielmożnego] J[ego]m[oś]ci X[ię]dza Andrzeja Stanisława Kostki na Załuskach Załuskiego biskupa płockiego i mazowieckiego I730 w Pułtusku.

Ref. no. B-34I: Rachunki dóbr biskupstwa płockiego na skarb biskupi trzymanych 1790-179I.

Ref. no. B-344: Rachunki dóbr biskupstwa płockiego na skarb biskupi trzymanych 1785-1786.

AGAD, APP (The Central Archives of Historical Records in Warsaw, The Economic Archive of Primate Michał Poniatowski)

Ref. no. 8o: Compendium Inventarium Archiepiscopatus Gnesenensis Post obitum Ill[ustrissi] mi et R[evren]d[is]simi D[omi]ni Joannis Stephini Wydzga Archiepiscopi Gnesenensis Sede Vacante in Amdministeatione Ill[ustrissi]mi D[omini]ni Stanislai Krajewski Decani Gnesenensis, Prepositi S. Michaelis in Arce Cracoviensis, Custodis Loviciensis, M[aioris] R[egni] Cancellariae Regentis. In Anno I685to Diebus Ultimis [Septem]bris Conscriptum.

APŁ, AMŁ, WT (State Archive in Łódź, City of Łódź Files, Technical Department)

Ref. no. 2II42: Plan części miasta Łodzi - z mapy geometry Starzyńskiego, w skali I:I68o redukował w I9I7 r. na skalę I:4000 geometra Kazimierz Jasiński, z warstwicami wg planu inż. Lindleya z $1903 \mathrm{r}$.

APŁ, RGP, Wa (State Archive in Łódź, Piotrków Governorate, Technical Department)

Ref. no. I66r: Plany pozostałe z akt zniszczonych za I883 r., skan I56-I57.

APŁ, RGP, wB (State Archive in Łódź, Piotrków Governorate, Construction Department)

Ref. no. I569: [Proekt] na postrojku Akcìonernym" Obŝestvom" bumažnyh" manufaktur" Karla Šejblera postrojku kamen[noj] Ino ètaž[noj] kladovoj pod" No 96I-969 po ulicě Sv[âtoj] Ėmilii $\mathrm{v}^{\prime \prime}$ gor[ode] Lodzi.

Ref. no. 1586: O perestrojkě Akcìnern[ym] Obŝestv[om] Bumažn[yh] Manufakt[ur] Karla Šejblera kamen[noj] Ino ètažn[oj] lavki i dostrojki kamen[noj] 2h" ètažn[oj] lavki s" žilymi poměšeniâmi na fabričnoj městnosti N 96I-969 po Pržendzâl'noj ulicě v" gor[ode] Lodzi.

Ref. no. I867: [Proekt] na postrojku Akcionernym" Obŝestvom" Bumažnyh" Manufaktur" Karla Šejblera kamen[nago] saraâ dlâ požarnyh" instrumentov" častû I-no ètaž[noû] i častû $4 h^{\prime \prime}$ ètaž[noû] s" trempelem" a ravno kamen[nyh] I-no ètaž[nyh] služb" $s$ " othožimi městami na městnosti No 96I do 969 po uli[ce] sv. Ėmilìi v" gor[ode] Lodzi.

Ref. no. 2248 O postrojkě Ino ètažnyh" čulanov" s" pračešnâmi i othožimi městami, perestrojkě kryši na kotel'nom" pokoě i dostrojkě kladovoj vo dvorovom" městě akcìonern[ogo] obŝ[estva] bum[ažnyh] manufaktur" K. Šejblera No 96r i 969 po ul[ice] Sv[âtoj] Èmilìi v" g[orode] Lodzi.

Ref. no. 3358 Ob" utverždenì plana na postrojku firmoû K[arl] Šejbler" v" g[orode] Lodzi po ul[ice] Sv[âtoj] Èmilìi kamennoj pristrojki i podvala.

APŁ, Zb.alb.ikon. (State Archive in Łódź, A collection of iconographic albums)

Ref. no. A-IO3, k. 2, photo I: Zakłady K. Scheiblera na Księżym Młynie - Ogólny widok.

APŁ, Zb.ikon. Sig (State Archive in Łódź, Iconographic collection, Scheibler and Grohman)

Ref. no. 239: Consum.

Ref. no. 240: Consum - Werkaufssaal. 
APŁ, Zb.kart. (State Archive in Łódź, Cartographic collection)

Ref. no. I: Plan goroda Lodzi Petrokovskoj gubernii sostavlen v" I894, I895 i I896 godach... Ref. no. 527: Plan der Gruntbesitzungen samt Fabricken Sener Hochwohlgeboren des Herrn Prezes Karl Schejbler mit der Umgebung der Stadt Lodz ausgearbeitet im Jahre I877 geschworener Jeometer der 2 Klasse Rudolph Micinski.

BFM (Bildarchiv Foto Marburg) sygn. fm931972.

\section{Literature}

Aterini B. (2007), Le ghiacciaie. Architetture dimenticate, Alinea, Firenze.

Baraniewski W. (2004), Kuchnia i stót w polskim dworze, Prószyński i S-ka, Warszawa. Beamon S.P., Roaf S. (1990), The Ice-houses of Britain, Routledge, London-New York.

Bochenek R.H. (2003), Twierdza Modlin, Bellona, Warszawa.

Brożkiewicz P.J. (1946), Chtodnictwo aprowizacyjne, Kraków.

Brückner E., Spillner E. (1904), Eisbehälter und Kühlanlagen mit künstlicher Kälteerzeugung, [in:] Handbuch der Architektur, T. 3, Die Hochbaukonstruktionen, Bd. 6, $3^{\text {rd }}$ ed., Stuttgart, p. 247-28I.

Bystrzonowski W. (1743), Jnformacya Matematyczna, Rozumnie ciekawego Polaka Swiat caty, Niebo, y ziemie, y co na nich iest $W$ trudnych kwestyach y praktyce iemuż utatwiaiaca..., $\mathrm{I}^{\text {st }}$ ed., Lublin.

Domaniewski C. (1929), Cegta normalna polska wymiarów $27 \times 13 \times 6 \mathrm{~cm}$ obowiazująca z mocy postanowienia Prezydenta Rzeczypospolitej Polskiej z dnia Is lipca roku 1927. Tablice ilości cegiet, zapraw i ich sktadników, Warszawa.

Ellis M. (1982), Ice and Icehouses Through the Ages. With a Gazetteer for Hampshire, n.p.

Encyklopedja rolnicza i rolniczo-przemystowa (I889), vol. II, ed. H. Kotłubaj, A. Strzelecki, Wydaw. "Rolnika i Hodowcy”, Warszawa, p. 380-38I.

Filipowicz P. (20I2), Wyniki badań architektonicznych zabytkowego budynku konsumów /sklepu dla pracowników/ zlokalizowanego przy ul. Księży Młyn I4 w Łodzi, w zespole poprzemysłowym Karola Scheiblera, Łódź (a computer printout in the archive of the Łódź Provincial Monument Conservator in Łódź).

Geul A. (I884), Brauereien, Mälzereien und Brennereien, [in:] Handbuch der Architektur, T. 4, Entwerfen, Anlage und Einrichtung der Gebäude, Hbd. 3, Landwirthschaftliche Gebäude und verwandte Anlagen, I ${ }^{\text {st }}$ ed., Darmstad, p. 396-43I.

Gostomski A. (I588), Gospodarstwo, Kraków.

Gubańska R. (2009), Budynki i budowle dolnoślaskich folwarków, Wydawnictwo Uniwersytetu Przyrodniczego, Wrocław (Uniwersytet Przyrodniczy we Wrocławiu. Monografie, 87).

Harres B. (1882), Die Landwirthschaftliche Baukunst. Praktisches Handbuch für Architekten und Bauhandwerker, ed. E. Harres, $2^{\text {nd }}$ ed., Berlin.

Harres B. (I883), Budownictwo wiejskie. Praktyczny podręcznik dla budowniczych i rzemieślników przy budownictwie pracujących, dla szkót rzemieślniczych i budownictwa, dla gospodarzy wiejskich i leśniczych, E. Harres (ed.), Warszawa. 
Haur J.K. (1675), Oekonomika ziemianska generalna Punktámi Pártikulárnemi, Interrogatoryámi Gospodárskiemi, Praktyka Mieśięczna, Modelluszámi abo Tabutámi Arithmetycznemi obiaśniona. Pánom Dźiedzicznym, Arendarzom, Oekonomom, Attendętom, Urzędnikom, Pisárzom Prowentowym y wszystkim wpospolitości Dobr żiemskich Dozorcom pozyteczna i potrzebna..., Kraków.

Haur J.K. (1679), Ziemianska generalna Oekonomika Obszernieyszym od przesztey edycyy Stylem Supplementowana, i we wszystkich Punktách znacznie poprawiona, Kraków.

Haur J.K. (1693), Sktad abo skarbiec Znákomitych Sekretow oekonomiey ziemiańskiey, Kraków.

Heintze N. (2008), Eiskeller, „Schattenwelt”, as cited on: https://www.berliner-unterwelten. de/verein/forschungsthema-untergrund/sonderbauten/eiskeller.html (access I VI 2020).

Heintze N. (2014), Esskeller und Eiswerke in Berlin und Brandenburg, $3^{\text {rd }}$ ed., Berlin, https://digital.zlb.de/viewer/resolver?urn=urn:nbn:de:kobv:Io9-opus-238023 (access 20 VI 2020).

Holewiński J. (1919), Budownictwo wiejskie. Podręcznik praktyczny dla wtaścicieli ziemskich, Towarzystwo Wydawnicze, Warszawa-Kraków.

Instrukcijos feodaliniu valdu administracjai Lietuvoje XVII-XIX a. (1985), publ. Z. Kiaupa, J. Kiaupiené, Vilnius.

Iwanicki K. (1917), Budownictwo wiejskie. Poradnik przy wznoszeniu zabudowań na wsi, Kijów-Warszawa.

IZJ (20I5a), Tajemniczy ceglany krag na Księżym Mtynie, "Express Ilustrowany", no. 240, October I4, p. I, 3 .

IZJ (2OI5b), Rozwiązano zagadkę tajemniczego kręgu. Okragta lodownia na Księżym Mtynie, "Express Ilustrowany", no. 25I, October 27, p. 3.

Kajzer E. (198I), Łódź. Konsumy w zespole robotniczego osiedla mieszkalnego K. Scheiblera "Księży Młyn” (Record Sheet of Architectural and Construction Monuments in the archive of the Provincial Office of Monument Preservation in Łódź).

Kamler J. (1910), Rzeźnie miejskie, "Przegląd Techniczny”, 48 (15), p. I89-193.

Kobojek G. (1998), Księży Mtyn. Królestwo Scheiblerów, Zora, Łódź.

Kola A. (1989), Późnośredniowieczna chtodnia z Torunia, "Acta Universitatis Nicolai Copernici. Nauki Humanistyczno-Społeczne. Archeologia”, I6 (200), p. IO3-II6.

Kostrzecki M. (1840), Lodownia, "Przewodnik Rolniczo-Przemysłowy", 4 (23), p. 264-265. Kowecka E. (199I), Dwór "Najrządniejszego w Polszcze magnata”, Інкм. PAN, Warszawa.

Kulesza M. (2013), Wielokulturowe dziedzictwo Eodzi a wspótczesny krajobraz miasta, "Studia z Geografii Politycznej i Historycznej”, 2, p. II-46.

Kurpisz W. (1952), Poradnik zlewniarza, Państwowe Wydawnictwa Techniczne, Warszawa.

Kurpisz W. (1956), Poradnik pracownika zlewni i śmietanczarni, $2^{\text {nd }}$ ed., Wydawnictwo Przemysłu Lekkiego i Spożywczego, Warszawa.

Kwiatkowski B. (20I2), Folwarki Lubelszczyzny. Historia rozwoju i zabudowy, Politechnika Lubelska, Lublin.

Kwiatkowski M. (2015), Tajemniczy budynek na Księżym Mtynie, "Gazeta Łódź”, a supplement to "Gazeta Wyborcza", no. 240, October I4, p. 4.

Lodownia wiejska (I865), "Przyjaciel Domowy”, 25, p. I00. 
Lütgert S.A. (2000), Eiskeller, Eiswerke und Kühlhäuser in Schleswig-Holstein und Hamburg. Ein Beitrag zur Kulturlandschaftsforschung und Industriearchäologie, Husum.

Mączyński J. (1564), Lexicon Latino Polonicum ex optimis Latinae linguae Scriptoribus concinnantum..., Regiomonti Borussiae.

Magnuszewska A. (2015), Archeolodzy zacznq wkrótce badać tajemniczy ceglany krąg na Księżym Mtynie, "Dziennik Łódzki”, ed. A, no. 240 (24.072), October I4, p. 4.

Markiewicz-Kozańska E. (1982), Historia budowy przedsiębiorstwa Karola Scheiblera w latach I854-I9I4, "Zeszyty Naukowe Politechniki Łódzkiej. Budownictwo", 408 (28), p. I23-I43.

Markiewicz-Kozańska E. (1984), Rozwój przestrzenny wielkich i dużych zespotów fabryczno-mieszkalnych na terenie w Eodzi w drugiej potowie XIX wieku, "Kwartalnik Architektury i Urbanistyki”, 29 (I-2), p. I37-I45.

Markiewicz-Kozańska E. (199I), Ze studiów nad rozwojem przestrzennym XIX-wiecznych zespotów zabudowy fabrycznej i mieszkalnej, "Zeszyty Naukowe Politechniki Łódzkiej. Budownictwo", 553 (42), p. 53-90.

Martin J. (1997), Glacières françaises. Histoire de la glace naturelle, Errance, Paris.

Martin J. (2000), Glaces naturelles et glacières, n.p.

O lodach. Wyjątek dla Gospodyń z P. Meineke (I822), "Izis Polska", I, p. 239-243.

Ostap. (I9II), Zmiana formatu cegty, "Architekt”, I2, (II-I2), p. I65-I66.

Ostrzeniewski A. (1902), Lodownie, "Architekt", 4, (9) (supplement), col. 39-44.

Ostrzeniewski A. (1906), O udziatowych lodowniach, "Architekt", 7 (3), col. 6I-62.

Pawłowski K., Stępień W., Lorenc-Karczewska A., Szelągowska E., Salm J., Wesołowski J., coop. M. Chronowski (200I), Delimitacja wschodniej części d. posiadeł wodno-fabrycznych (stadium rewitalizacji Księżego Młyna - etap I) (Regional Centre for Studies and the Protection of the Cultural Environment, Łódź, a computer printout in the archive of the Łódź Provincial Monument Conservator in Łódź).

Pierzchała W. (20I4), Sensacyjne odkrycia podczas rewitalizacji Księżego Mtyna, "Dziennik Łódzki”, ed. A, no. 256, November 4, p. 6.

Pierzchała W. (20I4a), Stary osadnik odkryty na Księżym Mtynie zostanie jednak zasypane, "Dziennik Łódzki”, ed. A, no. 260, November 8-9, p. 5.

Pietrzak J., Rybacki Z., Milczarek M. (20I5), Opracowanie z badań archeologicznych na fragmencie działki ewidencyjnej nr 84/2, obręb W-25 w Łodzi, AzP 66-52, na obszarze wpisanym do rejestru zabytków pod nr A/36r z dnia I4.I2.1996 r. Księży Młyn Lodownia, b (a printout in the archive of the Łódź Provincial Monument Conservator in Łódź).

Plank R. (1954), Geschichte der Kälteerzeugung und Kälteanwendung, [in:] R. Plank (ed.), Handbuch der Kältetechnik. Unter Mitarbeit zahlreicher Fachleute, Springer, Berlin-Heidelberg, p. I-I60, https://doi.org/Io.I007/978-3-662-II680-7_I

Ponętowski J. (1937), Ziemianin, [in:] S. Kot, Urok wsi i życia ziemiańskiego w poezji staropolskiej. Ksiega pamiątkowa na 75-lecie Gazety Rolniczej, Warszawa, p. I4I-I43.

Popławska I. (1964), Budownictwo domów robotniczych w Łodzi w drugiej potowie XIX w., "Kwartalnik Architektury i Urbanistyki", 9 (4), p. 295-3I2.

Popławska I. (1972), Zespót fabryczno-rezydencjonalny Księży Mtyn w Łodzi, "Kwartalnik Architektury i Urbanistyki”, I7 (4), p. 295-304. 
Popławska I. (1973), Architektura przemystowa Łodzi w XIX wieku, Państwowe Wydawnictwo Naukowe, Warszawa (Studia i Materiały do Teorii i Historii Architektury i Urbanistyki, II).

Popławska I. (1992), Architektura mieszkaniowa Łodzi w XIX wieku, Państwowe Wydawnictwo Naukowe, Warszawa (Studia i Materiały do Teorii i Historii Architektury i Urbanistyki, 19).

Puś W. (1979), Dzieje przedsiębiorstwa i zatogi w Polsce Ludowej 1945-1977, [in:] W. Puś, S. Pytlas, Dzieje Eódzkich Zaktadów Przemystu Bawetnianego im. Obrońców Pokoju "Uniontex" (d. Zjednoczonych Zaktadów K. Scheiblera i L. Grohmana) w latach 1827-1977, Państwowe Wydawnictwo Naukowe, Warszawa-Łódź, p. 309-525.

Pytlas S. (1979), Dzieje przedsiębiorstwa w latach I827-1945, [in:] W. Puś, S. Pytlas, Dzieje Łódzkich Zaktadów Przemystu Bawetnianego im. Obrońców Pokoju "Uniontex" (d. Zjednoczonych Zaktadów K. Scheiblera i L. Grohmana) w latach 1827-1977, Państwowe Wydawnictwo Naukowe, Warszawa-Łódź, p. 9-308.

Pytlas S. (1998), Księży Mtyn i okolice. Jego wtásiciele i ich zaktady, [in:] D. Berbelska, S. Pytlas, J. Salm, A. Zielińska, Księży Mtyn, Łódź, p. 15-4I.

Rausch de Traubenberg F. (1779), Elementa Architecturae ad structuras oeconomicas applicatae in usum Academiarum per Regnum Hungariae et eidem adnexas provincias conscripta, Budae.

Rausch de Traubenberg F. (I788), Budownictwo wieyskie do gospodarskich potrzeb stosowane a do uzycia kraiowego podane, [transl. C. Zapolski], Warszawa.

Reinink W. (1995), Eiskeller. Kulturgeschichte alter Kühltechniken, mit Beiträgen J.G. Vermeulen, M. Wehdorn, Böhlau, Wien-Köln-Weimar (Kulturstudien. Bibliothek Der Kulturgeschichte, I5), https://doi.org/IO.7767/9783205122548

Reinink W., Vermeulen J.G. (198I), IJskelders. Koeltechnieken van weleer, Heuff, Nieuwkoop.

Rozbicka M. (1999), Siedziby średniej i drobnej szlachty na pótnocno-zachodnim Mazowszu $w$ drugiej potowie XVIII i pierwszej potowie XIX wieku, Neriton, Warszawa.

Salm J. (1998), Wokót Księżego Mtyna - architektoniczne i urbanistyczne przemiany fabrycznej jurydyki, [in:] D. Berbelska, S. Pytlas, J. Salm, A. Zielińska, Księży Mtyn, Łódź, p. $43-87$.

Salm J. (200I), Problematyka konserwatorska Księżego Mtyna, czyli o szczycie góry lodowej, [in:] W. Kaczmarek (ed.), O Księżym Mtynie. Historia - architektura - ogrody. Materiaty z sesji zorganizowanej 2 marca 20oI r. w Rezydencji Księży Mtyn przez Oddziat Łódzki Towarzystwa Opieki nad Zabytkami oraz Muzeum Sztuki Rezydencja Księży Mtyn, Towarzystwo Opieki nad Zabytkami. Zora, Łódź, p. 43-63.

Salm J. (2007), Problematyka konserwatorska Księżego Mtyna, czyli o szczycie góry lodowej, [in:] Muzealizacja, Rewitalizacja czy Destrukcja? Wobec Dziedzictwa XIX-wiecznej Architektury, Łódzkie Towarzystwo Naukowe, Łódź, p. 69-8I.

Sieradzka A. (200I), Przechadzki po dawnych wnętrzach czyli jak niegdyśs mieszkano w Polsce, Oficyna Wydawnicza Volumen, Warszawa.

Stownik Barttomieja z Bydgoszczy. Wersja polsko-tacińska (1999-20I9), vol. I-VI, ed. E. Kędelska, I. Kwilecka, A. Łuczak, L.A. Jankowiak, Slawistyczny Ośrodek Wydawniczy, Warszawa.

Stefański K. (1994), Kilka uwag o architekturze Łodzi i jej twórcach, "Miscellanea Łódzkie”, I (II), p. I2-2O.

Stefański K. (1997), Legenda Hilarego Majewskiego, "Tygiel Kultury”, 3, p. 77-8I. 
Stefański K. (200I), Jak zbudowano przemystowa Łódź. Architektura i urbanistyka w latach I82I-I9I4, Regionalny Ośrodek Studiów i Ochrony Środowiska Kulturowego, Łódź.

Stefański K. (2003), Atlas architektury dawnej Łodzi do I939 r., It ed., Archidiecezjalne Wydawnictwo Łódzkie, Łódź.

Stefański K. (20I5), Wtoska podroż Hilarego Majewskiego, [in:] J. Malinowski, I. Gavrash, D. Ziarkowski (ed.), Polscy i rosyjscy artyści i architekci w koloniach artystycznych zagranica i na emigracji politycznej I8I5-1990, Polski Instytut Studiów nad Sztuką Świata. Wydawnictwo Tako, Warszawa-Toruń (Sztuka Europy Wschodniej, 3), p. 59-68.

Strzałkowski J. (1997), Architekci i budowniczowie w Łodzi do 1944 roku, Łódź.

Szewczyk J. (2019), Hydroizolacja elementów budowli w wybranych okresach historii architektury czyli o uszczelnieniach z nietypowych materiatów, o dawnych impregnatach, drenażach i pokrewnych rozwiązaniach budowlanych, Oficyna Wydawnicza Politechniki Białostockiej, Białystok.

Szyburska T. (1972), Łódź - osiedle domów dla robotników tzw. “Księży Młyn” i pałac Herbsta, Warszawa (a manuscript in the archive of the Łódź Provincial Monument Conservator in Łódź).

Szyburska T. (1976), Osiedle domów dla robotników tzw. 'Księży Mtyn' i patac Herbsta w Łodzi, [in:] W. Karczmarzyk (ed.), Dokumentacje naukowo-historyczne PKZ (I975), Warszawa, p. IOI-I35.

Szymański P. (2006), Księży Mtyn dolina nauki i sztuki - planowanie pasywne czy aktywne?, [in:] T. Markowski (ed.), Rewitalizacja kompleksu Księżego Mtyna, Warszawa (Biuletyn KPZK PAN, 229, CD-ROM), p. 58-86.

Świtkowski P. (1782), Budowanie wieyskie dziedzicom dóbr i possessorom toż wszystkim, iakążkolwiek zwierzchność po wsiach i miasteczkach mającym do uwagi y praktyki podane. Z figurami, Warszawa-Lwów.

Tangires H. (I99I), Icehouses in America: the History of a Vernacular Building Type, "New Jersey Folklife", I6, p. 33-43.

Tomczak A. (2012), 'Miasto $w$ mieście’ - ochrona struktury urbanistycznej posiadet wodno-fabrycznych w Eodzi, "Czasopismo Techniczne, Architektura", IO9 (3-A (I2)), p. 69-75.

Turowski A. (1976), Struktura przestrzenna zatożenia urbanistycznego Księży Mtyn, [in:] Znaczenie zabytków techniki i budownictwa XIX wieku w procesie przemian spotecznych (Materiaty z sesji naukowej odbytej $w$ Łodzi w dniach I7-I8 listopad 1975), Łódź, p. 67-82.

Turowski A. (1976a), Styl wzniosty i przestrzeń bogata. (Struktura przestrzenna zatożenia urbanistycznego Księży Mtyn), "Teksty”, 4-5 (28-29), p. I49-176.

Tynecki J. (1988), Przemyst a kultura dzieje imperium bawetnianego w Łodzi dla historyków kultury, "Prace Polonistyczne", ser. 44, p. 5-55.

Ulepszenia w browarach piwnych ostatniemi laty zapowiedziane (1867), "Gazeta Przemysłowa”, 2 (62), p. 38-39.

Walczak B.M. (2007), Księży Mtyn w kontekście rozwoju zespotów fabryczno-mieszkalnych w Europie, [in:] Muzealizacja, Rewitalizacja czy Destrukcja? Wobec Dziedzictwa XIX-wiecznej Architektury. A popular scientific session. The $7^{\text {th }}$ Festival of Science, Technology and Art in Łódź, Łódzkie Towarzystwo Naukowe, Łódź, p. 47-68. 
Walczak B.M. (2010), Zespoty fabryczno-mieszkalne w europejskim przemyśle wtókienniczym w latach I77I-I9I4. Geneza - rozwój - typologia, Wydawnictwo Politechniki Łódzkiej, Łódź (Zeszyty Naukowe Politechniki Łódzkiej, I084. Rozprawy Naukowe, 402).

Wawel, vol. II, Materiaty archiwalne do budowy zamku (1913), publ. A. Chmiel, Kraków (Teka Grona Konserwatorów Galicyi Zachodniej, 5).

Wilk A. (2000), Lodownie, "Spotkania z Zabytkami”, 24 (II) (I65), p. 37-38.

Włodarska D., Kamiński M., Frąckiewicz A., Kuba R., Kopka R. (20I6), Projekt budowlany remontu konserwatorskiego elewacji i dachu budynku dawnych Konsumów K.W. Scheiblera, wpisanych do Rejestru Zabytków nr A/36I, Łódź, ul. Księży Młyn I4, n.p. (a computer printout in the archive of the Łódź Provincial Monument Conservator in Łódź).

Włodarska D., Kamiński M., Frąckiewicz A., Kuba R., Kopka R., Pałuska M. (20ı6a), Projekt budowlany remontu konserwatorskiego elewacji i dachu budynku dawnych Konsumów K. W. Scheiblera, wpisanych do Rejestru Zabytków nr A/36I, Łódź, ul. Księży Młyn I4, n.p. (a computer printout in the archive of the Łódź Provincial Monument Conservator in Łódź).

Wystawa Przemystowo-Rolnicza w Warszawie w r. I885. V. Przemyst fabryczny tkacki (I885), "Przegląd Techniczny", 22 (II), p. IO8-II4.

Zaprutko-Janicka A. (20I7), Dwudziestolecie od kuchni. Kulinarna historia przedwojennej Polski, Znak, Kraków.

Zjednoczone Zaktady Wtókiennicze K. Scheiblera i L. Grohmana Spótka Akcyjna w Łodzi, [Łódź] [after 1934].

\section{Summary}

A Few Words About the Ice House of the Konsum Store in
the Nineteenth-Century Priest's Mill Factory and Residential Complex in Łódź

The issue of ice houses, both those found among manor and farm buildings and those connected with industrial plants, is a research issue frequently raised in many countries of Western Europe and in the United States. In the Polish literature, however, it does not attract much interest, which is why knowledge of it - or at least the knowledge shared - is usually limited to the awareness of the existence of ice houses and their purpose, and only occasionally do they become subjects of more extensive research. This also concerns the very material substance of such buildings.

In 2015, on the Priest's Mill estate in Łódź, erected along with the extension of Karol Scheibler's cotton plant at the beginning of the i870s, rescue excavations were conducted under the supervision of archaeologists Maciej Milczarek and Zbigniew Rybacki. They concerned the remains of an ice house built for the estate general store (including a grocery) called Konsum. Its preserved form is a result of a few construction stages completed in quick succession. During the third one (between $1883 / 1884$ and 1889 ) the ice house we are interested in was built. It was not big as its capacity was approximately roo cubic metres, and its structure was rather typical of larger industrial ice houses, with the upper (aboveground) chamber used as an ice warehouse, and the lower (underground) chamber 
serving as the store's cold storage. Most probably, it was not used for long, however, there is no data that would allow to determine the time of its liquidation.

Keywords: Priest's Mill in Łódź, industrial archaeology, ice house

\title{
Streszczenie
}

\author{
Kilka słów o lodowni sklepu „Konsum” w dziewiętnastowiecznym zespole \\ fabryczno-mieszkalnym: Księży Młyn w Łodzi
}

Zagadnienie lodowni, tak tych spotykanych wśród zabudowań dworskich i folwarcznych, jak i związanych z zakładami przemysłowymi, jest tematem badawczym często podejmowanym w wielu krajach zachodniej Europy oraz w Stanach Zjednoczonych. Natomiast w polskiej literaturze naukowej nie budzą one większego zainteresowania, w efekcie czego wiedza o nich - przynajmniej ta przekazywana - najczęściej ogranicza się do świadomości ich istnienia oraz przeznaczenia i tylko sporadycznie stają się one przedmiotem nieco szerzej zakrojonych badań. Dotyczy to także samej, materialnej substancji obiektów.

W 2015 r. w na łódzkim osiedlu „Księży Młyn”, zrealizowanym wraz z mającą swój początek w latach 70-tych XIX w. rozbudową zakładów bawełnianych Karola Scheiblera, pod kierunkiem archeologów Macieja Milczarka i Zbigniewa Rybackiego przeprowadzone zostały ratownicze badania wykopaliskowe. Ich przedmiotem były relikty lodowni wzniesionej dla potrzeb funkcjonującego tu w przeszłości wielobranżowego (m.in. spożywczego) sklepu osiedlowego, zwanego Konsumem. W swej zachowanej do dziś bryle powstał on w efekcie kilku szybko następujących po sobie etapów budowy, a w trzecim z nich (między I883/I884 a I889 r.) powstała interesująca nas tu lodownia. Nie był to obiekt wielki, gdyż jego kubaturę ocenić można na zbliżoną do około $100 \mathrm{~m}^{3}$, otrzymał zaś on dyspozycję typową raczej dla większych lodowni przemysłowych, w których to górna (nadziemna) komora służyła jako skład lodu, zaś dolna (zagłębiona w grunt) była „zimnym” magazynem sklepowym. Nie funkcjonował on zapewne zbyt długo, brak jednak podstaw dla próby dokładnego określenia czasu jego likwidacji.

Słowa kluczowe: Księży Młyn, archeologia przemysłowa, lodownia

\author{
Janusz Pietrzak \\ University of Lodz \\ Institute of Archaeology \\ Poland \\ e-mail: janusz.pietrzak@uni.lodz.pl
}

